\title{
An Empirical Study on the Financial Preparation for Retirement of the Independent Workers for Profit in Poland
}

\author{
Teresa H. Bednarczyk ${ }^{1}$, Ilona Skibińska-Fabrowska ${ }^{1}$ and Anna Szymańska ${ }^{2, *}$ \\ 1 Department of Insurance and Investments, The Faculty of Economics, Maria Curie-Sklodowska University in \\ Lublin, 20-031 Lublin, Poland; teresa.bednarczyk@umcs.lublin.pl (T.H.B.); \\ ilona.skibinska-fabrowska@mail.umcs.pl (I.S.-F.) \\ 2 Department of Insurance, The Faculty of Economics and Sociology, University of Lodz, 90-214 Lodz, Poland \\ * Correspondence: anna.szymanska1@uni.lodz.pl
}

Citation: Bednarczyk, Teresa H., Ilona Skibińska-Fabrowska, and Anna Szymańska. 2021. An Empirical Study on the Financial Preparation for Retirement of the Independent Workers for Profit in Poland. Risks 9: 160. https://doi.org/10.3390/ risks 9090160

Academic Editor: Grzegorz Zimon

Received: 20 July 2021

Accepted: 26 August 2021

Published: 1 September 2021

Publisher's Note: MDPI stays neutral with regard to jurisdictional claims in published maps and institutional affiliations.

Copyright: (C) 2021 by the authors. Licensee MDPI, Basel, Switzerland. This article is an open access article distributed under the terms and conditions of the Creative Commons Attribution (CC BY) license (https:// creativecommons.org/licenses/by/ $4.0 /)$.

\begin{abstract}
Modern pension schemes are based on the delegation of responsibility for pension provision from state institutions to individuals, which implies voluntary retirement saving. Workers for profit (independent workers in household market enterprises) hold much greater personal responsibility for financing their pensions than workers for pay. The main aim of this study was to provide an empirical identification of economic and social factors that would determine the propensity toward long-term saving for pensions by independent, for-profit workers in Poland. Additionally, the study recognizes the level of saving accumulated by them as well as preferred forms in which this saving is made.In order to select determinants of pension saving, a logistic regression model was used. The data come from the direct survey conducted in 2020 by CAWI method (Computer-Assisted Web Interview) on a random nationwide sample of Poles. The analysis of the data also used other methods of descriptive and mathematical statistics. The conducted research showed that the respondents individual decisions concerning saving for retirement are affected by such factors as gender, age, family situation, amount of revenue, share of revenue from business activity in total revenue, and subjective assessment of the respondents' financial situation. The respondents declared holding various, though not high, savings. Moreover, it turned out that independent workers for profit in Poland opt for non-conventional forms of gathering pension savings.
\end{abstract}

Keywords: self-employment; workers for profit; retirement savings; logistic regression model; Poland

\section{Introduction}

Workers in employment for profit $^{1}$ (self-employed) are natural persons who play a role of the owners of a company as well as persons providing services for it. In practice, they make up a very diversified social and professional group. This description covers both independent enterprises-employers and own-account workers without employees. The group of workers for profitalso includes dependent contractors and contributing family workers. In the Polish statistics, counterparts for independent workers for profit are employersin the private sector and self-employed persons without employees (GUS 2020b).

The trends concerning the share of workers for profit in the overall number of employees in different countries are variable and diverse (Blanchflower 2000; Zimon and Hossein 2021). They depend on a number of factors, both macroeconomic (European Economic and Social Committee 2011; Barba-Sanchez and Atienza-Sahuquillo 2017), and microeconomic-individual (Haapanen and Tervo 2009; Millan et al. 2012). Popularization of self-employment as a form of professional activity is also much affected by globalization (Pries and Seeliger 2013) as well as demographic factors and changes in the job market (Lesthaedge 2014). Over the last years in Poland, the number of self-employed workers has increased. According to the data for the 1Q 2020, the share of the self-employed in the total number of active persons (over $16.5 \mathrm{~m}$ ) was 18.5\% (where self-employed persons 
without employees account for $14.7 \%$ and employers in the private sector-3.8\%) (GUS 2020a). In Poland, a number of persons, including those with tertiary qualifications, prefer their own business activity as it gives them more autonomy and allows for flexibility while combining professional and private life or pursuing their own interests.

On the other hand, due to gaps in social protection provision, workers in employment for profit do not have any security for their financial situation after their business activity has ceased. Whereas both workers for pay and workers for profit are covered by a pension scheme guaranteed by the state, the self-employed pay premiums on slightly different principles. In Poland, a pension contribution for them is a flat-rate. The basis is a declared amount of revenues-not less, however, than $60 \%$ of the average monthly salary in the economy (in 2021 it is PLN 3155.40, i.e., approx. EUR $700^{2}$ ), and a mandatory old-age pension contribution of all the self-employed is PLN 615.95 (approx. EUR 140). Due to this, workers for profit pay relatively less than workers for pay. As it seems, the main stimulus for the rise in their number in recent years is of a fiscal nature, i.e., lower public levies. Moreover, in Poland workers for profit may exercise their rights to a number of reliefs in paying for social security contributions such as undeclared work, and full or partial exemption from the obligation to pay contributions during the start-up period of their business activity (for a total of the first five years). Unfortunately, low contributions will not guarantee them high pensions from the public scheme in the future, because the main factor determining the amount of their pensions is currently the sum of contributions paid throughout their working life.Regrettably, as many as $99 \%$ of persons running their own businesses pay only minimum contributions to the extent allowed by law and treat them as para-taxes. Very few persons decide to voluntarily increase this contribution above the obligatory lump sum.

However, the pension reform undertaken in 1999 dramatically changed the principles and the level of the pensions paid. The fact that pension benefits are based on the formula of the defined contribution instead of the defined benefit, and with the longer life expectancy in retirement, makes the public pension scheme increasingly less generous. Even today, average pension benefits for the self-employed in Poland are lower than average benefits paid out by $\mathrm{ZUS}^{3}$. Therefore, it would be reasonable to assume that in the future pension benefits of the self-employed are going to be even lower. If this is the case, it is necessary to seek for other alternative solutions that would allow to maintain the proper standard of living in retirement. Therefore, there are grounds to claim that in the future pensions of the self-employed will be even lower.

Although the debate on old-age provision for the self-employed has already been run for quite some time, it is still current and increasingly gaining in importance. A significant amount of research on this issue has been carried out in a number of countries; however, most of it hinges on the solutions applied in the Anglo-Saxon countries. In Poland, there is little empirical research referring to individual decisions on voluntary saving for retirement taken by independent workers for profit (self-employed). This has created a research gap that deserves to be filled. It is all the more important because the culture of accumulating voluntary pension savings is still not sufficiently developed in Poland.

The main purpose of the study is an empirical identification of factors that determine the propensity to long-term saving for determinants of independent workers for profit in Poland. An additional aim is to recognize the level of savings built up by them and their preferred forms of gathering these savings. The proportion of respondents declaring that they have retirement savings in the total number of respondents was adopted as a measure of the propensity to save, similarly to other researchers (Feng and Gerrans 2014; Pedroni and Rieskamp 2015; Cupák et al. 2019). 


\section{Literature Review and Hypothesis Development}

It is worth noting that among economists there is no full agreement as to what pension savings actually are. As a rule, the basic criterion of distinction is the motive to save money, understood as the need to accumulate resources for old age retirement (Keynes 1936; Katona 1975). However, other criteria are equally important, and these are as follows: their long-term accumulation (Fisher and Montalto 2010) or their long-term consumption (a phase of saving decumulation).

Long-term decumulation brings the risk of too rapid consumption of capital accumulated by saving for retirement (outliving retirement savings) (Pitacco et al. 2009). The faster the average eligibility age in retirement increases, the higher is the likelihood that a person may 'outlive' their savings. Having retirement savings is also associated with investment risk where the main person who bears such a risk is the saver (currently, in most countries defined contribution models DC are dominant). Another characteristic of retirement savings is a variety of forms (ways) in which they may be accumulated and deposited.

Retirement savings may be both voluntary and mandatory. Voluntary savings are accumulated with no duress, knowingly, giving up in part current consumption in favour of future consumption. Savings built up under duress result from the rules imposed by the state (e.g., savings as obligatory pension contributions, or mandatory employee pension programmes). Retirement savings may be accumulated both as financial resources and tangible goods, e.g., assets placed with one' own business undertaking. They may be accumulated individually, as well as in the institutionalized from as dedicated saving programmes with a view to retirement (additional pension pillars) ${ }^{4}$.

In the subject literature, one can find a division of retirement savings into conventional and non-conventional (Mastrogiacomo and Alessie 2014). Conventional retirement savings are pension schemes (pension plans, pension schemes, retirement plans, and retirement schemes), i.e., assets clearly distinguished and intentionally accumulated to secure retirement within a pension scheme. Non-conventional retirement savings include all other forms of private savings, accumulated outside the pension scheme in a given country (Mastrogiacomo and Alessie 2014). The discussed above considerations led to the formulation of the first research hypothesis concerning accumulation of retirement savings by the self-employed.

Hypothesis 1 (H1). Propensity to accumulate conventional retirement savings in pillar III by independent workers for profit in Poland is lower than propensity to accumulate retirement savings within non-conventional solutions (outside pillar III).

In the light of the subject literature, it should be concluded that the conditions for retirement savings are numerous and cover various factors. The results of the empirical research on the determinants of households' retirement savings are presented in many studies (Ares et al. 2015; Buchholtz et al. 2021). Those examining determinants of voluntary saving within individual pension schemes (pillar III) include, among others, (Guariglia and Markose 2000; Harju 2009; Le Blanc 2011; Fernández-López et al. 2010; Garcia and Marques 2017). In the Polish subject literature, there are not many studies that deal with determinants of voluntary saving in a more complex and comprehensive manner.

In the light of empirical research, carried out both in Poland and abroad, propensity to take individual decisions on saving in the context of retirement are affected by demographic features such as age, gender, or family status (Yang and DeVaney 2012); level of income (Turner and Manturuk 2012; Obben and Monique 2019; Amari et al. 2020); permanent income (Dynan et al. 2004); the level of material assets in the form of real property (Belke et al. 2015; Alessi et al. 2013; Lersch 2014); or accumulated assets (Ares et al. 2015). The existing research also deals with analyzing the relationship between retirement savings accumulated by households and the pension scheme itself-its structure and operating principles (Alessi et al. 2013; Yang and DeVaney 2012). The differences in choices regarding 
investments within pension schemes, on account of gender, were identified, among others, in Australia (Gerrans and Clark-Murphy 2004). Interdependencies between gender, retirement plans, and financial skills of the British were investigated, among others, by Farrar, Moizer, Lean and Hyde (Farrar et al. 2019).

Much less frequently than in the case of households, one may find the research on factors determining pension savings of workers for profit (Ramnath et al. 2017; Parker and Rougier 2007). The main category for these factors, which in empirical research proved to be statistically significant for retirement savings, is those of demographic nature such as age, family status, and the place of residence of the self-employed (DeVaney et al. 1997, 1998; Krupa and Damian 2016). Propensity of unincorporated enterprises to save for retirement is also impacted by their investment decisions because most of their financial and tangible assets (real estates) are at the same time their company assets. Compared to other workers, these business units are distinguished by wealth (Gentry and Glenn 2000; Ketkaew et al. 2019; Ramnath et al. 2017). It is worth noting that there are a lot of studies that identified new factors of psychological nature not examined before, such as, e.g., a feeling of control over one's life and savings. More often than workers for pay, workers for profit prefer pension schemes ensuring them more freedom of choice of schemes and greater investment risk (Karpowicz 2019). They are also more inclined to benefit from tax reliefs (Smith and Griesdorn 2014; Joulfaian 2018).

Another essential factor influencing propensity to gather retirement savings by workers for profit are revenues received in the course of running business activity (DeVaney et al. 1997; Ketkaew et al. 2019; Rossi and Sansone 2016). Due to higher risk taken and, consequently, higher income volatility than in the case of workers for pay, this issue seems to be particularly interesting.

Multiplicity and similarity of factors that influence gathering retirement savings by households and self-employed allowed one to formulate the second research hypothesis.

Hypothesis 2 (H2). In Poland, retirement savings held by independent workers for profit are determined by the same groups of factors as in the case of retirement savings of workers for pay, i.e.,by social and demographic as well as economic factors.

\section{Methodology}

A direct survey (collecting primary data) was carried out in December 2020 by CAWI (Computer-Assisted Web Interview) method on a nationwide random sample of 1067 natural persons running an individual non-agricultural business activity (active entrepreneurs) in Poland. The selection of the sample was representative in geographical terms (voivodeships by a registered business head offices), and in terms of business activity (the prevailing kind of activity by PKD 2007-the Polish Classification of Business Activity). Sampling frame was taken from the register of the Central Business Activity Records and Information. ${ }^{5}$ The study does not include persons engaged in agricultural activity (farmers are subject to different regulations of the pension scheme); partners of civil law partnerships; as well as persons of independent occupations and professions, dependent contractors, and contributing family members.The tool used in the study was a standardized direct interview questionnaire, which was attached to the article as an attachment [Appendix A]. The scope of the issues covered included, in particular, planned activities aimed at increasing the standard of living in the retirement period, indicative ranges of the respondents savings declared as retirement benefits, and financial instruments in which respondents had accumulated their private retirement savings. Information on the amount of accumulated funds is denominated in PLN and referred to EUR. A more detailed description of the research sample obtained is presented in Table 1. 
The validation of the used questionnaire was performed using the Cronbach's alpha reliability coefficient (Cronbach 1951).This ratio indicates how well a set of variables or items measures a single, one-dimensional hidden aspect. The higher the internal consistency of the questionnaire, the higher the value of Cronbach's alpha coefficient. In social research, the value of the coefficient should be greater than 0.6. The Alpha Cronbach coefficient in the study is 0.65 , which indicates that the questionnaire is sufficiently reliable.

Two research hypotheses have been verified in the study. In order to verify them, statistical methods such as statistical tests and a logistic regression model were used.

To verify H1, a parametric test was carried out for two samples according to Sheskin (Sheskin 2011). This test verifies the null hypothesis of the form:

$$
\mathrm{H}_{0}: p_{1}=p_{2}
$$

where $p_{1}$ and $p_{2}$ are, respectively, fractions of elements distinguished according to the selected trait in the first and second population. The test statistic is as follows:

$$
z=\frac{\hat{p}_{1}-\hat{p}_{2}}{\sqrt{p(1-p)\left(\frac{1}{n_{1}}+\frac{1}{n_{2}}\right)}}
$$

where $p=\frac{n_{1} \hat{p}_{1}+n_{2} \hat{p}_{2}}{n_{1}+n_{2}}$, and where $n_{1}$ the size of the first sample, $n_{2}$ the size of the second sample, $\hat{p}_{1}$ percentage of items distinguished in the first sample (in the survey of respondents accumulating retirement savings in additional pillars), and $\hat{p}_{2}$ percentage of elements distinguished in the second sample (in the survey of respondents collecting retirement savings under unconventional solutions). While the null hypothesis is true, the test statistic has an asymptotically normal standardized distribution.

The verification of the second research hypothesis (H2) was performed with the use of the regression model. The logistic regression model was chosen due to the dichotomy of the dependent variable. The method of logistic regression is often utilized in research on determinants of accumulating retirement savings (Buchholtz et al. 2021; Gerrans and Clark-Murphy 2004; Hauff et al. 2020; Joo and Grable 2005).

In a logistic regression model, dependent variable $Y$, referred to as the outcome variable, is a zero one variable with value 1 when the case occurs and value 0 when the case does not occur. The probability of $Y=1$ is modelled taking quantitative and qualitative variable as endogenous variables. Introducing quantitative variables, one should transform them by means of zero-one transformation and identify the reference group to which interpretation of model estimates are related. The selection of the reference group is based on substantive grounds arising from the nature of the examined case. The logistic regression model is expressed as follows:

$$
P(Y=1)=\frac{1}{1+e^{-\left(\beta_{0}+\beta_{1} X_{1}+\ldots+\beta_{k} X_{k}\right)}}
$$

The parameters of this model are estimated by the maximum likelihood method, looking for such estimates of structural parameters $\beta_{j}$, which would maximize likelihood of the sample. This model allows one to estimate so called odds ratios ${ }^{6}$ marked with Exp (B) or OR, which determines a relative probability (risk) of the event occurrence-how many times the estimated probability will change along with the increase of $X_{j}$ by unit (for continuus variables), or how many times it is higher or lower in the examined group in relation to the reference group (for quantitative exogenous variables). When the received odds ratio is more than 1 , that means that the factor described by a given exogenous variable stimulates the probability of the event occurrence-the probability is increasing on average OR-times with the increase of $X_{j}$ by unit or for the examined group it is on average OR-times higher than for the reference group. The 0 odds ratio means the lack of relation between the exogenous variable and evaluated probability. The odds ratio 
$0<\operatorname{Exp}(B)<1$ means that the factor described by a given exogenous variable destimulates the probability for the event to occur, i.e., the odds that a given event will occur decreases on average OR-times together with the increase of $X_{j}$ by unit or for the examined group, and the odds are on average OR-times lower than for the reference group. The evaluation of the significance of model parameters is performed bythe Wald test. The evaluation of goodness of fit for empirical data is run by The Hosmer-Lemeshow test (test verifying the fit of the model; the test is not recommended when there are quantitative variables), an omnibus test of the model coefficients (chi-square test verifying the significance of model coefficients) and pseudo coefficients R2 by Cox and Snell, pseudo R2 by Nagelkerke (these coefficients indicate a better fit of the model the closer their value is to 1). The evaluation of the logistic regression model also includes the evaluation of classification properties, that is, prognostic accuracy, on the basis of the classification table. The classification table presents the accuracy of the classification " 1 " and " 0 " of the model and the so-called count $\mathrm{R} 2$, reflecting the accuracy of the overall model classification (the closer to 1 the values, the better the prognostic properties of the model).

Table 1 presents the characteristics of the research sample related to social and demographic factors of independent workers for profit, such as gender; age; marital status; family situation; education; and economic variables directly connected with business activity such as years and type of activity performed, monthly income, revenue share from business activity in the total income of a household, and subjective assessment of financial situation of (their) wealth. Due to space limitation, Table 1 does not present the structure of the research sample by voivodships or PKD (the Polish Classification of Activities).

Table 1. Responses: descriptive statistics.

\begin{tabular}{|c|c|c|}
\hline Variable & $N=1067$ & $\%$ Age \\
\hline \multicolumn{3}{|l|}{ Age } \\
\hline under 35 & 166 & 15.6 \\
\hline between $36-50$ & 468 & 43.9 \\
\hline over 50 & 433 & 40.6 \\
\hline \multicolumn{3}{|l|}{ Gender } \\
\hline male & 719 & 67.4 \\
\hline female & 348 & 32.6 \\
\hline \multicolumn{3}{|l|}{ Education } \\
\hline primary and vocational & 29 & 2.7 \\
\hline secondary & 171 & 16.0 \\
\hline higher & 867 & 81.3 \\
\hline \multicolumn{3}{|l|}{ Marital status } \\
\hline singles & 284 & 26.6 \\
\hline persons in relationships & 743 & 69.6 \\
\hline $\begin{array}{l}\text { others (widower, widow, divorced, or } \\
\text { legally separated) }\end{array}$ & 40 & 3.8 \\
\hline \multicolumn{3}{|l|}{ Family situation } \\
\hline persons without dependent children & 590 & 55.3 \\
\hline persons with dependent children & 477 & 44.7 \\
\hline \multicolumn{3}{|l|}{$\begin{array}{l}\text { Type of business activity in household } \\
\text { market enterprises *: }\end{array}$} \\
\hline own-account workers without employees & 705 & 66.1 \\
\hline $\begin{array}{l}\text { employers in household market } \\
\text { enterprises }\end{array}$ & 362 & 33.9 \\
\hline
\end{tabular}


Table 1. Cont.

\begin{tabular}{|c|c|c|}
\hline Variable & $\mathbf{N}=1067$ & $\%$ Age \\
\hline $\begin{array}{l}\text { Business activity in years } \\
\text { up to } 5 \\
\text { over } 5\end{array}$ & $\begin{array}{l}241 \\
826\end{array}$ & $\begin{array}{l}22.6 \\
77.4\end{array}$ \\
\hline $\begin{array}{l}\text { Share of revenues from business in total } \\
\text { income of a household: } \\
\text { the only income } \\
\text { main income } \\
\text { complementary income }\end{array}$ & $\begin{array}{l}467 \\
368 \\
232\end{array}$ & $\begin{array}{l}43.8 \\
34.5 \\
21.7\end{array}$ \\
\hline $\begin{array}{l}\text { Estimated monthly revenues from business } \\
\text { activity in the last year: } \\
\text { below PLN } 2500 \text { (approx. EUR 550) } \\
\text { between PLN } 2500 \text { and PLN } 4500 \text { (EUR } \\
550 \text { to 1000) } \\
\text { between PLN } 4500 \text { and PLN } 6500 \text { (EUR } \\
1000 \text { to approx. EUR 1500) } \\
\text { above PLN } 6500 \text { (over EUR 1500) }\end{array}$ & $\begin{array}{l}164 \\
194\end{array}$ & $\begin{array}{l}19.0 \\
47.4\end{array}$ \\
\hline $\begin{array}{l}\text { Self-assessment of financial situation } \\
\text { (tangible assets held-real properties and } \\
\text { other goods } \\
\text { bad } \\
\text { average } \\
\text { good }\end{array}$ & $\begin{array}{l}126 \\
509 \\
432\end{array}$ & $\begin{array}{l}11.8 \\
47.7 \\
40.5\end{array}$ \\
\hline
\end{tabular}

In the research, the respondents declared their age, then the entire age group was divided into three age groups: up to 35 years (young people), between 36 and 50 (mature people), and over 50 (older people). It turned out that almost $44 \%$ of the respondents were adults, and older people accounted for almost $41 \%$. The smallest number of people were young, only $15.6 \%$. Among the respondents, the vast majority $(67.4 \%)$ were men and people with higher education ( $81.3 \%$ ). The most numerous group (almost $70 \%$ ) were people in relationships (families). When it came to the family situation, there was a slight majority (55\%) of people who no longer had children to support.

The respondents were asked to indicate the type of their own activity. Based on their responses, it turned out that the largest group of respondents (over $66 \%$ of respondents) were own-account workers without employees, with $34 \%$ of employers in household market enterprises.

Almost $50 \%$ of respondents declared that they achieve high revenues from their activities (average monthly income at a level exceeding PLN 6500, i.e., the average monthly gross salary in the Polish economy), and only $15 \%$ of them at a low level (below PLN 2500 - below the minimum monthly salaries in Poland). The rest of the respondents achieve revenues in the range of PLN 2500-6500 (between EUR 550-1500). For almost $80 \%$ of the surveyed respondents, income from business activity had a significant share in the household budget, being the only or the main source of it. For about $20 \%$ of the respondents, it constituted a supplementary income, which proves that business activity is conducted as an additional job. Most of the respondents, when asked to assess their financial situation, admitted that it was average (almost 50\%); $40 \%$ of the respondents assessed it as good, and only $12 \%$ of the respondents assessed their financial situation as bad. 


\section{Results}

Table 2 presents the results of the survey on the respondents' planned strategies ${ }^{7}$ to maintain the standard of living during retirement, should the public-pillar retirement pension turn out to be too low. The respondents had the opportunity to select more than one answer from the list of options given to them.

Table 2. Planned strategies of respondents, if the pension from the public pillar turned out to be too low.

\begin{tabular}{lcc}
\hline \multicolumn{1}{c}{ Answers } & $\mathbf{N}=\mathbf{1 0 6 7}$ & $\%$ \\
\hline $\begin{array}{l}\text { If a pension provided by ZUS turned out to be } \\
\text { insufficient, what would you do to achieve a desired } \\
\text { standard of living? }\end{array}$ & & \\
\hline I would use my own retirement savings & 632 & 39.2 \\
\hline I would count on possible inheritance or donation & 38 & 72.9 \\
\hline I would still continue professional activity & 778 & 23.0 \\
\hline $\begin{array}{l}\text { I would sell the assets of my own company(own } \\
\text { business) or its part }\end{array}$ & 245 & 11.6 \\
\hline $\begin{array}{l}\text { I would count on remuneration (or pension)of the } \\
\text { spouse/life partner }\end{array}$ & 124 & 0.9 \\
\hline I would take out a loan in the bank & 10 & 24.2 \\
\hline $\begin{array}{l}\text { I would consider letting a part of my flat; its sale; } \\
\text { or purchase of a smaller one in a different, } \\
\text { cheaper location }\end{array}$ & 258 \\
\hline $\begin{array}{l}\text { I would expect emergency financial aid from } \\
\text { immediate family / friends }\end{array}$ & 33 & 3.1 \\
\hline I do not know, I have never thought about it & 25 & 2.3 \\
\hline I find my pension from ZUS sufficient & 22 & 2.1 \\
\hline
\end{tabular}

The data in Table 2 shows that only 22 respondents $(2.1 \%)$ believe that their pension from ZUS will be sufficient to maintain their standard of living at retirement age. The rest of them do not believe it and have different ideas to supplement their public-pillar pension. Four main planned strategies emerge from the respondents' answers. The first one is maintaining further professional activity (almost $73 \%$ of responses); the second is using one's own retirement savings (almost 60\%); the third is to rent a part of the apartment or sell it, or to buy a smaller one in another, cheaper area $(24.2 \%)$; and the fourth is to sell the property of one's own company (own business) or a part of it $(23.0 \%)$.

It should be noted that most of the respondents (almost $\frac{3}{4}$ ) presented an optimistic assumption as to their health and expressed their willingness to continue earning a living in retirement, although in Poland there is a low economic activity rate of people in retirement age-in 2020 it was 8.8\% (GUS 2020c). However, other studies show that self-employed people tend to stay in the labor market longer than employees and retire much later (Parker and Rougier 2007). It follows that the vast majority of independent workers in household market enterprises in Poland are more aware than other socio-professional groups. This assumes that they will not be able to accumulate sufficient retirement savings and plans to fill the retirement gap with income from work at retirement age. As confirmed by other studies conducted in Poland among people aged 65+, people with retirement savings are much less likely to continue gainful employment during retirement than people with low savings, which applies to both women and men (Bielawska 2019). Extending the working life (longer work) of all workers is nowadays not only an increasingly achievable but also an increasingly effective way of increasing consumption in old age. As a result of longer work, the amount of time during which individuals will be dependent on retirement 
income decreases, and the length of working life increases, by which individuals can save more for retirement.

The data in Table 2 also shows that the majority of respondents feel responsible for securing additional income for retirement. About $60 \%$ of them plan to improve their financial situation during the retirement period on the basis of their own savings. Almost a quarter of respondents consider releasing the capital accumulated in residential real estate by renting a part of the apartment or selling it and buying a smaller one in another, cheaper area. This solution is practiced in many highly developed countries. Additionally, almost $1 / 4$ of the respondents plan to sell their own company's assets (own business) or a part of it and thus finance the retirement gap. This is in line with the opinion often found in the literature that an entrepreneur's business wealth is the best source of his retirement income. Interestingly, such ideas of filling the pension gap as living on credit or income support from children or a spouse/partner are practically of little importance for the respondents.

An important manifestation of retirement precaution is the accumulation of additional, long-term savings by economically active people, which in the future may become a source of supplementing their retirement income from the public pillar. In the survey, the respondents were asked to declare an amount range from the list of options provided to them, reflecting the level of their retirement savings, apart from ZUS and OFE.

Table 3 presents the results of a survey on the willingness of respondents to voluntarily accumulate retirement savings.

Table 3. The respondents' tendency to save for the retirement period.

\begin{tabular}{lll}
\hline \multicolumn{1}{c}{ Answers } & $\mathbf{N}=\mathbf{1 0 6 5}$ & $\%$ \\
\hline $\begin{array}{l}\text { Amount of retirement savings you currently } \\
\text { hold excluding ZUS and OFE, i.e., accumulated } \\
\text { in IKE, IKZE, or other investment instruments: }\end{array}$ & & \\
\hline no savings & 201 & 18.8 \\
\hline less than PLN 30,000 (EUR 8 6.7 thousand) & 321 & 30.1 \\
\hline $\begin{array}{l}\text { between PLN 30,000 and PLN 100,000 } \\
\text { (between EUR 6.7 and 22.2 thousand) }\end{array}$ & 258 & 24.2 \\
\hline $\begin{array}{l}\text { between PLN 100,000-200,000 (between EUR } \\
\text { 22.2 and 44.5 thousand) }\end{array}$ & 124 & 11.6 \\
\hline $\begin{array}{l}\text { between 200,000 PLN a 300,000 PLN } \\
\text { (between EUR 44.5 and 66.7 thousand) }\end{array}$ & 53 & 5.0 \\
\hline $\begin{array}{l}\text { more than PLN 300,000 (more than } \\
\text { EUR 66.7 thousand) }\end{array}$ & 110 & 10.3 \\
\hline $\begin{array}{l}\text { In which particular financial instruments are } \\
\text { your retirement savings deposited? }\end{array}$ & 257 & 24.1 \\
\hline IKE, IKZE & 151 & 14.2 \\
\hline investment funds & 491 & 46.0 \\
\hline real property & 140 & 13.1 \\
\hline gold/works of art, etc. & 140 & 13.1 \\
\hline securities & & \\
\hline
\end{tabular}


Table 3. Cont.

\begin{tabular}{lcc}
\hline \multicolumn{1}{c}{ Answers } & $\mathbf{N}=\mathbf{1 0 6 5}$ & $\%$ \\
\hline $\begin{array}{l}\text { life insurance as an investment (life } \\
\text { insurance with an insurance capital } \\
\text { fund-UFK) }\end{array}$ & 160 & 15.0 \\
\hline$\quad$ bank deposits & 233 & 21.8 \\
\hline $\begin{array}{l}\text { I invest in the company on a regular basis as } \\
\text { I treat development of my own business as a } \\
\text { particular 'pension scheme' }\end{array}$ & 284 & 26.6 \\
\hline $\begin{array}{l}\text { I do not hold any voluntary retirement } \\
\text { savings/investments }\end{array}$ & 201 & 18.8 \\
\hline
\end{tabular}

When assessing the mere fact of declaring or not declaring any pension savings by independent workers for profit in Poland, it should be stated that their propensity to save turned out to be relatively high ${ }^{9}$. As many as $81.2 \%$ of the respondents declared having some retirement savings. This may be justified by a comparatively good financial situation. Nearly half of the respondents declared their monthly income above PLN 6500 (slightly above the average remuneration ${ }^{10}$ in Poland).

It is interesting to compare the results of our study with the Aegon 2016 study, which shows that it systematically saves for retirement $29 \%$ of sole proprietors (people working for themselves without employees; freelancers; gig economy workers; agency workers; contractors; and seasonal workers) and $44 \%$ for retirement of the self-employed employing others (Aegon 2016, p. 12). Other studies using the Global Findex database from 2014 show that only about 25 percent of adult people worldwide save for old age, with rates in excess of 35 percent observed in high-income OECD countries and the East Asia-Pacific region (Demirgüç-Kunt et al. 2016). Therefore, from our research it can be concluded that the tendency to accumulate savings for old age of independent workers in household market enterprises in Poland is higher than the tendency of other social groups, both in Poland and in the world.

When it comes to retirement savings accumulated in the form of various assets, it should be noted that their declared level is varied and generally rather low. Only $10.3 \%$ of respondents declare retirement savings above 300,000. PLN (equivalent to approx. EUR 66.7 thousand ${ }^{11}$ ), which, considering the conditions of Poland, can be considered a significant amount from the point of view of increasing the adequacy of future pensions. The rest of the respondents still have relatively low retirement savings.

Voluntary retirement savings of people working for profit are low not only in Poland. As shown by empirical research, this professional group also has low savings in the Netherlands (Karpowicz 2019, Mastrogiacomo and Alessie 2014). For example, in Great Britain, the percentage of self-employed people saving for retirement in private capital plans is steadily declining, from almost 50\% in 1998 to less than 20\% in 2018 (Crawford and Karjalainen 2020, p. 6). Based on this, it can be concluded that the mere recognition of the retirement motive as valid does not immediately and directly translate into additional retirement savings, which is visible both among the self-employed and employees (Mastrogiacomo and Alessie 2014). This may result from such premises as delaying making a decision to save or myopia (Buchholtz et al. 2021).

According to the data collected in Table 4 saving in a conventional form, IKE (Individual Pension Account) and IKZE (Individual Pension Security Account) are accumulated by only a quarter of the respondents- $30 \%$ of all those holding any savings. This may prove that either the self-employed are ignorant of the possibility for accumulating retirement savings in this manner or that they are wary of making a decision in this respect, for whatever reason. Unfortunately, this issue was not the subject of this study. 
Table 4. Forms of collecting retirement savings by respondents.

\begin{tabular}{lll}
\hline \multicolumn{1}{c}{ Variable } & $\mathbf{N}=\mathbf{1 0 6 7}$ & $\%$ \\
\hline $\begin{array}{l}\text { In which particular financial instruments are } \\
\text { your retirement savings deposited?(you can } \\
\text { choose multiple answers) }\end{array}$ & & \\
\hline IKE, IKZE & 257 & 24.1 \\
\hline investment funds & 151 & 14.2 \\
\hline real property & 491 & 46.0 \\
\hline gold/works of art, etc. & 140 & 13.1 \\
\hline securities & 140 & 13.1 \\
\hline $\begin{array}{l}\text { life insurance as an investment (life insurance } \\
\text { with an insurance capital fund-UFK) }\end{array}$ & 160 & 15.0 \\
\hline $\begin{array}{l}\text { bank deposits } \\
\text { I invest in the company on a regular basis as I } \\
\text { treat development of my own business as a } \\
\text { particular 'pension scheme' }\end{array}$ & 233 & 21.8 \\
\hline $\begin{array}{l}\text { I do not hold any voluntary retirement } \\
\text { savings/investments }\end{array}$ & 284 & 26.6 \\
\hline
\end{tabular}

Among non-conventional instruments of gathering retirement savings, real properties prevail ( $46 \%$ of the respondents and over a half of those who hold any savings). This is also characteristic for workers for profit in other countries. Interestingly enough, over a quarter of the respondents treat investment in their own enterprises as a specific 'pension scheme'. Among traditional financial instruments most common are bank deposits ( $21.8 \%$ indications), life assurance with an investment character ( $15 \%$ indications), and investment fund units in investment funds ( $14.2 \%$ indications). In order to evaluate the structure of the retirement saving forms of the respondents, Hypothesis 1 was subject to verification.

The first research hypothesis (H1) assumes that in Poland, propensity of independent workers for profit to accumulate conventional retirement savings in pillar III is lower than propensity to accumulate retirement savings within non-conventional solutions (outside pillar III).

The truth of the hypothesis was verified with the previously discussed test for two proportions. The null hypothesis was verified in the form:

$\mathbf{H}_{0}: \mathrm{p}_{1}=\mathrm{p}_{2}$ (the percentage of independent workers for profit in Poland accumulating conventional retirement savings in the pillar III $\left(\mathrm{p}_{1}\right)$ is the same as the percentage of independent workers for profit in Poland accumulating retirement savings within nonconventional solutions $\left(\mathrm{p}_{2}\right)$, against the alternative hypothesis in the following form:

$\mathbf{H}_{1}: \mathrm{p}_{1}<\mathrm{p}_{2}$ the percentage of independent workers for profit in Poland accumulating conventional retirement savings in the pillar III $\left(\mathrm{p}_{1}\right)$ is lower than the percentage of independent workers for profit in Poland accumulating retirement savings within non-conventional solutions $\left(\mathrm{p}_{2}\right)$.

At the significance level 0.05, the test rejected the null hypothesis in favour of the alternative hypothesis (test statistics value $\mathrm{z}=-14.3, \mathrm{z}_{0.05}=1.65$ ). Therefore, one may state that the percentage of independent workers for profit in Poland who accumulate retirement savings in pillar III is lower than the percentage of Polish independent workers for profit accumulating unconventional savings (outside pillar III). On this basis, our research findings may be translated into the whole population of independent workers for profit in Poland, and we may claim that the first research hypothesis (H1) was verified positively. 
The endogenous variable of the model was the possession of retirement savings declared by a respondent (if a respondent declares holding retirement savings outside ZUS and OFE, a variable takes value 1 , but when he/she does not declare holding retirement savings, the variable is 0 ). Potential variables and coding qualitative variables are presented in Table 5 .

Table 5. Variables introduced into the model and coding variables.

\begin{tabular}{|c|c|}
\hline Variable & Coding \\
\hline \multirow{2}{*}{$\begin{array}{l}\text { Declaration of holding retirement savings } \\
\text { outside ZUS and OFE }\end{array}$} & 1-possess \\
\hline & 0 -does not posses \\
\hline Age & $\begin{array}{l}1 \text {-under } 35 \\
2 \text {-between } 36-50 \\
3 \text {-over } 50\end{array}$ \\
\hline \multirow{2}{*}{ Gender } & 1-female \\
\hline & 2-male \\
\hline Education & $\begin{array}{l}\text { 1-primary and vocational } \\
\text { 2-secondary } \\
\text { 3-higher }\end{array}$ \\
\hline Marital status & $\begin{array}{l}\text { 1-single } \\
\text { 2-persons in relationships } \\
\text { 3-other }\end{array}$ \\
\hline \multirow{2}{*}{ Family situation } & 1-persons without dependent children \\
\hline & 2-persons with dependent children \\
\hline \multirow{2}{*}{$\begin{array}{l}\text { Type of business activity in household } \\
\text { market enterprises }\end{array}$} & 1-own-account workers without employees \\
\hline & 2-employers in household market \\
\hline \multirow{2}{*}{ Business activity in years } & $1-$ up to 5 \\
\hline & 2 -over 5 \\
\hline $\begin{array}{l}\text { Share of revenues from business activity in } \\
\text { total income of a household }\end{array}$ & $\begin{array}{l}\text { 1-the only income } \\
\text { 2-main income } \\
\text { 3-complementary income }\end{array}$ \\
\hline $\begin{array}{l}\text { Estimated monthly incomes from business } \\
\text { activity in the last year } 2019\end{array}$ & $\begin{array}{l}\text { 1-less than PLN } 2500 \\
\text { 2-between PLN 2500-4500 } \\
\text { 3-between PLN 4500-6500 } \\
\text { 4-more than PLN 6500 }\end{array}$ \\
\hline $\begin{array}{l}\text { Self-assessment of financial situation (tangible } \\
\text { assets, held real estate and other } \\
\text { tangible goods) }\end{array}$ & $\begin{array}{l}1 \text {-bad } \\
2 \text {-average } \\
3 \text {-good }\end{array}$ \\
\hline
\end{tabular}

Exogenous variables in the conducted study were variables characterized in Table 5. For calculations, IBM SPSS Statistics was used. The Wald test allowed one to eliminate from the model variables that were statistically insignificant. The estimation results of the model taking into account only variables statistically significant were presented in Table 6 . The evaluation of the model fit and its classification parameters allow one to conclude that the model is well-fitted. Omnibus Test of Model Coefficients points at statistic's significance of at least one of the exogenous variables $(p$-value $=0)$. Nagelkerke $\mathrm{R}^{2}$ indicates that the model in $21.1 \%$ explains variance of the dependent variable. Since the model includes qualitative variables, the results of the Hosmer and Lemeshow test do not provide a proper evaluation of the model. Evaluating the quality of the classification, the model provides '1s.', i.e., respondents holding retirement savings with validity of $96.9 \%$. Total $\mathrm{R}^{2}$ is $82.7 \%$ which means that independent variables explain variability of endogenous variable in $82.7 \%$. 
Table 6. Estimation of the logistic regression model—declared retirement savings of independent workers for profit in Poland-statistically significant variables.

\begin{tabular}{|c|c|c|c|c|c|c|}
\hline Variable & B & S.E. & Wald Statistic & \multicolumn{2}{|c|}{ Significance } & $\operatorname{Exp}(B)$ \\
\hline \multicolumn{7}{|c|}{ Gender } \\
\hline male & 0.668 & 0.175 & 14.557 & 0.000 & $* * *$ & 1.950 \\
\hline \multicolumn{7}{|c|}{ Family situation } \\
\hline $\begin{array}{l}\text { persons with dependent } \\
\text { children }\end{array}$ & -0.381 & 0.188 & 4.100 & 0.043 & * & 0.683 \\
\hline $\begin{array}{l}\text { Share of revenues from } \\
\text { business in total income } \\
\text { of a household }\end{array}$ & & & 9.363 & 0.009 & $* *$ & \\
\hline main income & 0.615 & 0.212 & 8.438 & 0.004 & $* * *$ & 1.850 \\
\hline complementary income & 0.442 & 0.233 & 3.584 & 0.058 & & 1.555 \\
\hline $\begin{array}{l}\text { Estimated monthly } \\
\text { incomes from business } \\
\text { activity in the last year }\end{array}$ & & & 22.130 & 0.000 & $* * *$ & \\
\hline PLN 2500-4500 & 0.293 & 0.253 & 1.338 & 0.247 & & 1.340 \\
\hline PLN 4500-6500 & 0.740 & 0.277 & 7.154 & 0.007 & $* *$ & 2.096 \\
\hline above PLN 6500 & 1.178 & 0.268 & 19.309 & 0.000 & $* * *$ & 3.247 \\
\hline $\begin{array}{l}\text { Self assessment of } \\
\text { financial situation }\end{array}$ & & & 41.473 & 0.000 & $* * *$ & \\
\hline average & 1.117 & 0.228 & 23.961 & 0.000 & $* * *$ & 3.055 \\
\hline good & 1.750 & 0.275 & 40.346 & 0.000 & $* * *$ & 5.753 \\
\hline Age & & & 8.151 & 0.017 & $* *$ & \\
\hline between $36-50$ & 0.506 & 0.251 & 4.060 & 0.044 & * & 1.659 \\
\hline over 50 & -0.49 & 0.245 & 0.040 & 0.841 & & 0.952 \\
\hline Stable & -1.042 & 0.324 & 10.359 & 0.001 & $* * *$ & 0.353 \\
\hline $\mathrm{N}$ & 1067 & & & & & \\
\hline Cox i Snell's R-squared & 0.131 & & & & & \\
\hline Nagelkerke's R-squared & 0.211 & & & & & \\
\hline Log likelihood & 882.881 & & & & & \\
\hline Chi-square & 6.051 & & & & & \\
\hline $\begin{array}{l}\text { Hosmer-Lemeshow } \\
\text { (p-value) }\end{array}$ & 0.642 & & & & & \\
\hline \multicolumn{7}{|c|}{ Percentage of significant classifications } \\
\hline 0 & 21.4 & & & & & \\
\hline 1 & 96.9 & & & & & \\
\hline in total & 82.7 & & & & & \\
\hline
\end{tabular}

Notes: Statistical significance at the: ${ }^{* * *} p<0.005,{ }^{* *} p<0.01,{ }^{*} p<0.05$.

In the received model, the following predicators proved to be statistically significant: gender, age, family situation, income, income share from business activity in total income, and subjective assessment of financial situation.

\section{Discussion}

Gender is a primary and at the same time the most frequently analysed demographic factor in the literature that influences the attitudes and behaviours of the employed towards retirement security. The estimation results of the parameters in our model indicate that gender is ceteris paribus significantly correlated with the probability of holding retirement savings by the respondents. For males, the odds to possess such savings are on average 1.57 higher than for females. These results are in line with those obtained in the earlier research dealing both with households in general and with the self-employed.

Amari (Amari et al. 2020), Ares (Ares et al. 2015), Fernández-López (Fernández-López et al. 2015), and others researchers (Rey-Ares et al. 2019) indicated a higher level of saving 
among males. However, Hermansson (Hermansson 2017) showed that gender is not an essential distinguishing factor for retirement savings accumulated by clients of the Swedish banks.

Age turns out to be equally frequent demographic determinant of saving. On the basis of the results of our model, one may state ceteris paribus that persons aged between 36 and 50 have 1.66 times higher odds to hold retirement savings than respondents aged 35. The research by Rickwood and White (2009) shows that 'the border line' for beginning supplementary saving for retirement is age 40 . Before this age, retirement is deemed to be a too remote period of life to start saving for. It follows that the saving profile by age resembles a hump. In the middle period of life, savings are the highest, and low or non-existent, at young age or in retirement. Similar results are presented in the research by Goodfellow (Madigan et al. 2007). A quite distinct shift in the attitude towards savings for retirement security is noted once children become financially independent.

The estimated amount of the declared monthly incomes from business activity statistically has a significant effect on the respondents' retirement savings. Ceteris paribus, in the case of the respondents declaring their monthly savings between PLN 4500 and 6500 (from EUR 1000 to approx. EUR 1500), the odds to possess retirement savings increases 2.09 times, and those declaring incomes over PLN 6500-as many as 3.25 times compared with incomes of the respondents with incomes lower than PLN 2500 (approx. EUR 550). It may be assumed that this result is consistent with the existing state of knowledge in this area. The income level (permanent and current) was identified as a determinant for the level of retirement savings in all types of businesses, including the self-employed (Obben and Monique 2019; Amari et al. 2020; Ketkaew et al. 2019; DeVaney et al. 1997; Mutran et al. $1997)^{12}$. In the subject literature, there is also a mention of a statistically significant positive relation between the average income in the long-term and the level of savings (Dynan et al. 2004).

In the light of our research findings, the income share from business activity in the respondents' total income also proves to be a statistically significant determinant that boosts retirement savings. Ceteris paribus in the case of the respondents whose income from business activities is the main source of income, the odds for holding retirement savings increase almost twice (1.85) when set against entrepreneurs for whom revenues from running business are the main source of income. We consider this result to be in line with the existing knowledge in this area, because persons who receive incomes from other sources, e.g., from wage labour, are more likely to have better access to private pension schemes.

Another statistically significant factor that has impact on accumulation of retirement savings by the respondents is a subjective evaluation of their financial situation (wealth). With the assumption that other factors are at the same level, for the respondents who consider their financial situation as average, the odds for such savings increase 3.06 times, while for the entrepreneurs who find their financial situation good enough it increases 5.75 times, when compared with the persons who claim their financial situation is bad. In turn, in accordance with the empirical studies run by Mayer (Mayer et al. 2011), the hypothesis propensity to save for retirement increases together with the increase in wealth was not confirmed as explicitly positive. Such reliance was not recorded for households, where the head of the family was under 40 . Yet, the focus of our research is not so much on the impact of accumulated wealth on propensity to gathering retirement savings, as in other analyses (DeVaney et al. 1997; Lersch 2014; Ares et al. 2015), but rather on a subjective evaluation of the financial situation of the respondents.

In our model, a family situation is a significant variable. Assuming that other factors are at the same level, for the respondents with dependent children, the odds to hold such savings are 1.46 times lower than the respondents with no dependent children. Similarly, the results from other research show that the increase in a number of household members has a negative impact on attitudes and decisions regarding retirement security (Joo and Grable 2005). 
The model does not indicate statistical significance of such variables as marital status, education of the head of the family, type of business, and number of years running business as a sole trader. The lack of statistical significance of education came as a surprise, because in a number of empirical studies on households, it was proved to be noticeably significant. It may result from the fact that in the sample, there was a low percentage of persons with primary and secondary education compared with persons with higher education. A positive correlation between the level of education of the head of the household, the saving rate, and the amount of household savings-regardless the gender of the head of the family_was found by many researchers (Mori 2019; Beckmann et al. 2013).

The research does not cover all the possible determinants of accumulating voluntary retirement savings by the self-employed. One quite interesting aspect worth further research in the future might be the analysis of how retirement awareness may influence holding and accumulating resources for future retirement.

The subsequent research may be directed towards the profound analysis of the impact of gender and age on the type and forms of holding voluntary retirement savings by the self-employed. This, however, would require collecting primary data in a different way and ensuring that at the stage of the data collection, the research sample is representative with respect to the given characteristics.

\section{Conclusions}

The main goal of the conducted research was to identify factors that determine holding retirement savings by a specific group of professionally active persons, i.e., workers for profit in Poland, as well as to identify the level of savings they accumulated and the forms of accumulation they prefer. The study presents a dichotomous approach-conventional and non-conventional forms of retirement savings. Two research hypotheses were subject to verification.

The first stage of the analysis investigated whether the respondents take into account using their voluntary retirement savings if their old age pension from the public scheme was insufficient. It turned out that nearly $60 \%$ of the respondents consider this option. Therefore, it may be stated that holding and accumulating voluntary retirement savings is important for the self-employed. However, the fact remains that the level of accumulated savings is relatively low. Only $10 \%$ of the respondents have retirement savings over PLN 300,000 (approx. EUR 65 thousand). Another concern is that almost 20\% of the respondents declared no voluntary retirement savings or investments, at all. The respondents prefer non-conventional forms of accumulating retirement savings as only $25 \%$ of them make use of dedicated savings schemes in pillar III connected with some tax reliefs. It proves their low attractiveness from the point of view of the respondents or the lack of the respondents knowledge on this. The statistical tools applied in the study allow one to generalize this conclusion with reference to the population of workers for profit in Poland.

The second stage of the research was the identification of determinants of saving of workers for profit. The attempts were made to investigate whether the same groups of the determinants, identified in the earlier research and related to the saving decisions in working households, also affect individual decisions related to retirement saving of workers for profit. It turned out that there are no significant differences in demographic factors. Those that were statistically significant appeared to be also those indicated in other research, i.e., gender, and age family situation. The analysis did not confirm, as in the case of other research, any impact of education on pro-saving attitudes of the self-employed. Regarding economic factors, statistically significant determinants are, e.g., income, income share from business activity, and subjective assessment of financial situation. It is interesting to note that neither the type of business activity nor the period when it is run have influence on retirement saving, although, as it may seem, both of these factors might affect the income level, which in our research turned out to be statistically significant.

In summary, the following conclusions may be drawn from the presented study: 
1. Voluntary retirement savings are, for self-employed persons, a significant, although not the most important, way to supplement their future pension from the public pillar.

2. The self-employed prefer non-conventional forms (outside pillar III) of accumulating voluntary savings dedicated to their retirement, and-among these forms-holding real property and investing in one's own business are the most prevalent.

3. Retirement savings from self-employment are affected by various demographic, economic, and social factors, and their impact varies.

The main limitations encountered by the authors in the study were related to the selection of the sample. The sample is representative in terms of geography (voivodship according to the seat of the business) and in terms of the type of business (according to PKD 2007-Polish Classification of Activities). However, at the present stage of the research, it was not possible to construct a research sample taking into account representativeness in terms of the gender, age, and education of the respondents. In the opinion of the authors, such an analysis is desirable and should be carried out but at the next stage of the planned research. The authors also take into account the fact that the respondents' answers could have been influenced by the particular economic situation in which the survey was conducted, i.e., a period of the pandemic crisis, a dynamic increase in real estate prices, and an extremely low level of interest rates.

Author Contributions: Conceptualization, T.H.B.; I.S.-F., and A.S.; methodology, T.H.B. and A.S.; formal analysis, A.S.; investigation, T.H.B.; I.S.-F., and A.S.; resources, T.H.B. and I.S.-F.; data curation; T.H.B.; I.S.-F., and A.S.; writing — original draft preparation, T.H.B.; I.S.-F., and A.S.; writing—review and editing, T.H.B.; I.S.-F., and A.S.; visualization, I.S.-F. All authors have read and agreed to the published version of the manuscript.

Funding: This research received no external funding.

Institutional Review Board Statement: The study was conducted in accordance with the best practices for economic sciences.

Informed Consent Statement: Informed consent was obtained from all subjects involved in the study.

Data Availability Statement: The data presented in this study are available on request from the corresponding author.

Conflicts of Interest: The authors declare no conflict of interest.

\section{Appendix A}

Survey questionnaire

1. If a pension provided by ZUS turned out to be insufficient, what would you do to achieve a desired standard of living (you can choose multiple answers):

(a) I would use my own retirement savings

(b) I would count on possible inheritance or donation

(c) I would still continue professional activity

(d) I would sell the assets of my own company (own business) or its part

(e) I would count on the remuneration (or pension) of my spouse/life partner

(f) I would take out a loan from the bank

(g) I would consider letting a part of my flat; its sale; or the purchase of a smaller one in a different, cheaper location

(h) I would expect emergency financial aid from immediate family/friends

(i) I do not know, I have never thought about it

(j) I find my pension from ZUS sufficient enough

2. Please provide an indicative amount of retirement savings you currently hold excluding ZUS and OFE, i.e., accumulated in IKE, IKZE, or other investment instruments:

a. no savings

b. less than PLN 30,000 (EUR. 6.7 thousand) 
c. between PLN 30,000 and PLN 100,000 (between EUR 6.7 and 22.2 thousand)

d. between PLN 100,000 and 200,000 (between EUR 22.2 and 44.5 thousand)

e. between 200,000 PLN and 300,000 PLN (between EUR 44.5 and 66.7 thousand)

f. more than PLN300,000 (more than EUR 66.7 thousand)

3. In which particular financial instruments are your retirement savings deposited? (you can choose multiple answers):

g. IKE, IKZE

h. investment funds

i. real property

j. gold/works of art, etc.

k. securities

1. life insurance as an investment (life insurance with an insurance capital fundUFK)

m. bank deposits

n. I invest in my company on a regular basis as I treat the development of my own business as a particular 'pension scheme'

o. I do not hold any voluntary retirement savings/investments

Information about respondents

(1) Gender:

i. male

ii. female

(2) Age:

(3) Education:

i. primary and vocational

ii. secondary

iii. higher

(4) Marital status:

i. single

ii. person in relationships

iii. others (widower, widow, divorced, or legally separated)

(5) Family situation:

i. persons without dependent children

ii. persons with dependent children

(6) Type of business activity:

i. own-account workers without employees

ii. employers in household market enterprises

(7) PKD code classification:

i. SECTION A-Agriculture, forestry, and fishing

ii. SECTION B-Mining and quarrying

iii. SECTION C-Manufacturing

iv. SECTION D-Electricity, gas, steam, and air conditioning supply

v. SECTION E-Water supply, sewerage, waste management, and remediation activities

vi. SECTION F-Construction

vii. SECTION G-Wholesale and retail trade, repair of motor vehicles and motorcycles

viii. SECTION H-Transportation and storage

ix. SECTION I-Accommodation and food service activities

x. SECTION J-Information and communication

xi. SECTION K-Financial and insurance activities

xii. SECTION L-Real estate activities 
xiii. SECTION M-Professional, scientific, and technical activities

xiv. SECTION N-Administrative and support service activities

xv. SECTION O-Public administration and defence, compulsory social security

xvi. SECTION P-Education

xvii. SECTION Q-Human health and social work activities

xviii. SECTION R-Arts, entertainment, and recreation

xix. SECTION S-Other service activities

xx. SECTION T-Activities of households and employers, undifferentiated goods and services producing activities of households for own use

xxi. SECTION U-Activities of extraterritorial organizations and bodies

(8) Voivodship according to the seat of the business:

i. dolnośląskie

ii. kujawsko-pomorskie

iii. lubelskie

iv. lubuskie

v. łódzkie

vi. małopolskie

vii. mazowieckie

viii. opolskie

ix. podkarpackie

x. podlaskie

xi. pomorskie

xii. śląskie

xiii. świętokrzyskie

xiv. warmińsko-mazurskie

xv. wielkopolskie

xvi. zachodniopomorskie

(9) Business activity run in years:

i. up to 5

ii. over 5

(10) Estimated monthly income from business activity in the year 2019:
i. less than PLN 2500
ii. between PLN 2500 and PLN 4500
iii. between PLN 4500 and PLN 6500
iv. more than PLN 6500

(11) Income share from business activity intotal income:

$\begin{array}{ll}\text { i. } & \text { the only income } \\ \text { ii. main income } \\ \text { iii. complementary income }\end{array}$

(12) Self-assessment of financial situation (tangible assets held-real properties and other goods

$\begin{array}{ll}\text { i. } & \text { bad } \\ \text { ii. } & \text { average } \\ \text { iii. } & \text { good }\end{array}$

Notes

Following the terminology of International Classification of Status in Employment of 2018 (ICSE-18), the term workers in employment for profit refers to persons who bear the economic risk related to the loss of funds or other resources due to self-employment. Moreover, they are persons independent of another person or an economic unit in terms of work organization and/or market access. Workers in employment for profit have been divided into two groups: employers in household market enterprises and own-account workers in household market enterprises (solo-self-employed). Employment for profit, unlike employment for pay (paid employment), is traditionally called self-employment (ILO 2018). 
2 EUR 1 = PLN 4.4958 at the NBP mid-rate as of 21 May 2021 (NBP 2021).

3 In 2021, an average pension paid out by ZUS was a gross amount of PLN 2421.17 (approx. EUR 530), and an average pension of workers for profit was a gross amount 1950.61 PLN (approx. EUR 430) (GUS 2020a).

4 In most countries, pension schemes are based on three pillars: pillar I—public, regarded as basic; pillar II—private, regarded as additional one, based on active participation of employers (occupational pension plans); and pillar III—private, additional, based on individual foresight.

5 This is an official register of companies with the information on all the sole traders in Poland.

6 Odds ratio is defined as the probability ratio that a given event will occur to the probability that it does not occur (Field 2017).

7 The word strategy is a rather conventional term here, because it does not refer to written or formalized emergency financial plans but only to informal plans made by the self-employed.

$81 \mathrm{EUR}=$ PLN 4.4958 at the NBP mid-rate as of 21 May 2021 (NBP 2021).

9 From a microeconomic perspective, the basic measure of the propensity to save is the saving rate, defined as the share of savings in the disposable income of households. On a macroeconomic scale, the ratio of household sector savings to GDP is often used as a measure of households' propensity to save. In empirical (comparative) studies, the propensity to save is often analyzed on the basis of the share of savers in a given population of respondents (Feng and Gerrans 2014; Pedroni and Rieskamp 2015; Cupák et al. 2019). In this study, the share of respondents declaring that they have retirement savings in the total number of respondents was adopted as a measure of the propensity to save.

10 According to GUS (Statistics Poland), in 2020, the average monthly remuneration in national economy was PLN 5 167.47 (annual-PLN 62 009.64), (GUS 2020d).

$111 \mathrm{EUR}=$ PLN 4.4958 at the NBP mid-rate as of 21 May 2021 (NBP 2021).

12 Interestingly, the increase in revenues positively correlates with savings accumulated for old age security, and consumers with higher incomes have a more negative attitude towards ending their professional activity and retiring.

\section{References}

Aegon. 2016. Retirement Preparations in a New Age of Self-Employment, The Aegon Retirement Readiness Survey 2016. Available online: https:/ /www.aegon.com/contentassets/96b24267a54849309f492485832cff9f/retirement-self-employed-report.pdf (accessed on 20 August 2021).

Alessi, Rob, Viola Angelini, and Peter van Santen. 2013. Pension Wealth and Household Savings in Europe. Evidence from SHARELIFE. European Economic Review 265: 308-28. [CrossRef]

Amari, Mouna, Salhi Bassem, and Jarboui Annis. 2020. Evaluating the Effects of Sociodemographic Characteristics and Financial Education on Saving Behavior. International Journal of Sociology and Social Policy 40: 1423-38. [CrossRef]

Ares, Lucia Rey, Sara Fernández Lopez, and Milagros Vivel Bua. 2015. The Determinants of Privately Saving for Retirement: The Cases of Portugal and Spain. European Journal of Applied Business and Management 1: 69-92.

Barba-Sanchez, Virginia, and Carlos Atienza-Sahuquillo. 2017. Entrepreneurial Motivation and Self-Employment: Evidence from Expectancy Theory. International Entrepreneurship and Management Journal 13: 1097-115. [CrossRef]

Beckmann, Elisabeth, Hake Mariya, and Urvova Jarmila. 2013. Determinants of Households' Savings in Central, Eastern and Southeastern Europe. Available online: https://ideas.repec.org/a/onb/oenbfi/y2013i3b1.html (accessed on 5 August 2021).

Belke, Ansgar Hubertus, Dreger Christian, and Ochmann Richard. 2015. Do Wealthier Households Save More? The Impact of Demographic Facto. International Economics E Economic Policy 12: 163-73.

Bielawska, Kamila. 2019. Economic activity of Polish pensioners in the light of quantitative research. Equilibrium. Quarterly Journal of Economics and Economic Policy 14: 149-65. [CrossRef]

Blanchflower, David G. 2000. Self-employment in OECD Countries. Labour Economics 7: 471-505. [CrossRef]

Buchholtz, Sonia, Jan Gaska, and Marek Góra. 2021. Myopic Savings Behaviour of Future Polish Pensioners. Risks 9: 36. [CrossRef]

Crawford, Rowena, and Heidi Karjalainen. 2020. Retirement Saving of the Self-Employed. London: The Institute for Fiscal Studies, Available online: https:/ /ifs.org.uk/uploads/R181-retirement-saving-of-the-self-employed.pdf (accessed on 29 July 2021 ).

Cronbach, Lee J. 1951. Coefficient alpha and the internal structure of tests. Psychometrika 16: 297-334. [CrossRef]

Cupák, Andrej, Guergui I. Kolev, and Zuzana Brokešová. 2019. Financial Literacy and Voluntary Savings for Retirement: Novel Causal Evidence. The European Journal of Finance 25: 1606-25. [CrossRef]

Demirgüç-Kunt, Asli, Leora Klapper, and Georgios A. Panos. 2016. Saving for Old Age. WB Policy Research Working Paper Series, 7693; Washington: World Bank, pp. 1-41. [CrossRef]

DeVaney, Sharon A., Deanna L. Sharpe, Young Kratzer Constance, and Ya-Ping Su. 1998. Retirement Preparation of the Nonfarm Self-employed. Financial Couseling and Planning 9: 53-60.

DeVaney, Sharon A., Ya-Ping Su, Constance Young Kratzer, and Deanna L. Sharpe. 1997. Retirement Savings of Nonfarm Self-employed Workers: An Exploratory Study. Consumer Interest Annual 43: 58-63.

Dynan, Karen E., Skinner Jonathan, and Stephen P. Zeldes. 2004. Do the Rich Save More? Journal of Political Economy 112: 397-444. [CrossRef] 
Farrar, Sue, Moizer Jonathan, Lean Jonathan, and Hyde Mark. 2019. Gender, Financial Literacy, and Preretirement Planning in the UK. Journal of Women $\mathcal{E}$ Aging 31: 319-39. [CrossRef]

Fernández-López, Sara, Otero Luis, Vivel Milagros, and Rodeiro David. 2010. What are the driving forces of individuals' retirement saving? Czech Journal of Economics and Finance 60: 226-51.

Fernández-López, Sara, Milagros Vivel-Búa, Otero-González Luis, and Durán-Santomil Pablo. 2015. Exploring the gender effect on Europeans' retirement savings. Feminist Economics 21: 118-50. [CrossRef]

Feng, Jun, and Gerrans. 2014. Patterns of Voluntary Worker Retirement Savings: A Longitudinal Analysis. (psu.edu). Available online: http:/ / citeseerx.ist.psu.edu/viewdoc/download?doi=10.1.1.661.6025\&rep=rep1\&type=pdf (accessed on 14 May 2021).

Field, Andy. 2017. Discovering Statistics Using IBM SPSS Statistics, 5th ed. London: SAGE, pp. 1115-251.

Fisher, Patti J., and Catherine P. Montalto. 2010. Effect of saving motives and horizon on saving behaviors. Journal of Economic Psychology 31: 92-105. [CrossRef]

Garcia, Maria Teresa Medeiros, and Pedro Deslandes Correia Vasconcelos Marques. 2017. Ownership of individual retirement accounts-An empirical analysis based on SHARE. International Review of Applied Economics 31: 69-82. [CrossRef]

Gentry, William M., and Hubbard R. Glenn. 2000. Entrepreneurship and Household Saving. NBER Working Paper Series; Berkeley: Berkeley Electronic Press, p. 7894.

Gerrans, Paul, and Marilyn Clark-Murphy. 2004. Gender Differences in Retirement Savings Decisions. Journal of Pension Economics and Finance 3: 145-64. [CrossRef]

Guariglia, Alessandra, and Sheri Markose. 2000. Voluntary Contributions to Personal Pension Plans: Evidence from the British Household Panel Survey. Fiscal Studies 21: 469-88. [CrossRef]

GUS. 2020a. LabourForce Survey in Poland III Quarter 2020. Available online: https://stat.gov.pl/en/topics/labour-market/workingunemployed-economically-inactive-by-lfs/labour-force-survey-in-poland-iii-quarter-2020,2,39.html (accessed on 8 May 2021)

GUS. 2020b. Methodological Report Statistics on Labor Market, Wages and Salaries. Warszawa: Statistics Poland.

GUS. 2020c. Information Regarding the Labour Market in the Fourth Quarter of 2020. Available online: https://stat.gov.pl/obszarytematyczne/rynek-pracy/pracujacy-bezrobotni-bierni-zawodowo-wg-bael/monitoring-rynku-pracy-kwartalna-informacjao-rynku-pracy-w-czwartym-kwartale-2020-r-,12,45.html (accessed on 18 August 2021).

GUS. 2020d. Average Monthly Gross Wage and Salaryin National Economy in 2020. Available online: https://stat.gov.pl/en/lateststatistical-news / communications-and-announcements/list-of-communiques-and-announcements/average-monthly-grosswage-and-salary-in-national-economy-in-2020,283,8.html (accessed on 24 May 2021).

Haapanen, Mikka, and Hannu Tervo. 2009. Self-employment duration in urban and rural locations. Applied Economics 41: $2449-61$. [CrossRef]

Harju, Jarko. 2009. Voluntary Pension Savings: The Effects of the Finish Tax Reform on Savers' Behavior. Working Papers 2009/22. Barcelona: Institutd'Economia de Barcelona (IEB).

Hauff, Jeanette C., Anders Carlander, Tommy Gärling, and Gianni Nicolini. 2020. Retirement Financial Behavior: How Important Is Being Financially Literate? Journal of Consumer Policy 43: 543-64. [CrossRef]

Hermansson, Cecillia. 2017. Saving Motives, Gender, and the Use of Financial Advisory Services. Managerial Finance 43: $1202-23$. [CrossRef]

ILO. 2018. 20th International Conference of Labour Statisticians. Available online: https:/ /www.ilo.org/wcmsp5/groups/public/--dgreports/---stat/documents/publication/wcms_644596.pdf (accessed on 20 August 2021).

Joo, So-Hun, and John E. Grable. 2005. Employee Education and the Likelihood of Having a Retirement Savings Program. Journal of Financial Counseling and Planning 16: 37-49.

Joulfaian, David. 2018. Saving for retirement by the self-employed. Journal of Pension Economics E Finance 17: 316-34. [CrossRef]

Karpowicz, Izabela. 2019. Self-Employment and Support for the Dutch Pension Reform. IMF Working Paper. Washington: International Monetary Fund, p. 64.

Katona, George. 1975. Psychological Economics. New York: Elsevier.

Ketkaew, Chavis, Martine Van Wouwe, and Preecha Vichitthammaros. 2019. Exploring how an entrepreneur financially plans for retirement income: Evidence from Thailand. Cogent Business \& Management 6: 2-15. [CrossRef]

Keynes, John Maynard. 1936. The General Theory of Employment, Interest and Money. London: Macmillan.

Krupa, Dorota, and Walczak Damian. 2016. Savings of Households Run by Self-Employed Persons in Rural Areas in Poland. In Business Challenges in the Changing Economic Landscape. Eurasian Studies in Business and Economics, no. 2/2. Berlin and Heidelberg: Springer, vol. 2, Available online: https:/ /link.springer.com/chapter/10.1007/978-3-319-22593-7_34\#citeas (accessed on 8 May 2021).

Le Blanc, Julia. 2011. The Third Pillar in Europe: Institutional Factors and Individual Decisions. Deutsche Bundesbank Discussion Paper, Series 1: Eco-nomic Studies No 09/2011; Hessen: Deutsche Bundesbank.

Lersch, Philipp M. 2014. Do Homeowners Save More? A Longitudinal Analysis for the UK and Germany. HOMECOME Working Paper Series No. 9. Cologne: University of Cologne.

Lesthaedge, Ron. 2014. The Second Demographic Transition: A Concise Overview of its Development. Proceedings of the National Academy of Sciences 111: 18112-15. [CrossRef]

Madigan, Elinor M., Marianne Goodfellow, and Jeffrey A. Stone. 2007. Gender, perceptions and reality: Technological literacy. SIGCSE Bull 39: 410-14. [CrossRef] 
Mastrogiacomo, Mauro, and Rob J. M. Alessie. 2014. Where Are the Retirement Savings of Self-Employed? An Analysis of Unconventional Retirement Accounts. De Nederlandsche Bank Working Paper, No. 454. Amsterdam: Netherlands Central Bank.

Mayer, Robert N., Cathleen D. Zick, and Mitchell Marsden. 2011. Does Calculating Retirement Needs Boost Retirement Savings? The Journal of Consumer Affairs 45: 175-200. [CrossRef]

Millan, Jose Maria, Congregado Emilio, and Román Concepcion. 2012. Determinants of self-employment survival in Europe. Small Business Economics 38: 231-58. [CrossRef]

Mori, Neema. 2019. Determinants of Individual Savings Among Tanzanian's. Review of Behavioral Finance 11: 352-70.

Mutran, Elizabeth J., Donald C. Reitzes, and Maria E. Fernandez. 1997. Factors that Influence Attitudes toward Retirement. Research on Aging 19: 251-73. [CrossRef]

NBP. 2021. Exchange Rates. Available online: https:/ / www.nbp.pl/homen.aspx?f=/kursy/kursyen.htm (accessed on 21 May 2021).

Obben, James, and Waayer Monique. 2019. New Zealand's Old-Age Pension Scheme and Household Saving. International Journal of Social Economics 38: 767-88. [CrossRef]

European Economic and Social Committee. 2011. Opinion of the European Economic and Social Committee on "New Trends in Self-Employed Work: The Specific Case of Economically Dependent Self-Employed Work", Official Journal of the European Union 2011/C 18/08. Brussels: European Economic and Social Committee.

Parker, Simon C., and Jonathan C. Rougier. 2007. The retirement behaviour of the self-employed in Britain. Applied Economics 39: 697-731. [CrossRef]

Pedroni, Andreas, and Jorg Rieskamp. 2015. Psychological Factors of Voluntary Retirement Saving. Available online: researchgate.net (accessed on 14 May 2021).

Pitacco, Ermanno, Michel Denuit, and Steven Haberman. 2009. Modelling Longevity Dynamics for Pensions and Annuity Business. New York: Oxford University Press.

Pries, Ludger, and Martin Seeliger. 2013. Work and Employment Relations in a Globalized World: The Emerging Texture of Transnational Labor Regulation. Global Labour Journal 4: 26-47. [CrossRef]

Ramnath, Shanthi, John B. Shoven, and Sita N. Slavov. 2017. Pathways to Retirement through Self-Employment. NBER Working Paper, No. 23551. Cambridge: Cambridge University Press.

Rey-Ares, Lucia, Sara Fernández-López, Maria Milagros Vivel-Búa, and Ruben Lado-Sestayo. 2019. The early bird catches the retirement savings. Qualitative Research in Financial Markets. [CrossRef]

Rickwood, Catherine, and Lesley White. 2009. Pre-purchase decision-making for a complex service: Retirement planning. Journal of ServicesMarketing 23: 145-53. [CrossRef]

Rossi, Maria Christina, and Dario Sansone. 2016. Precautionary Savings and the Self-Employed. Small Business Economics 51: 105-27. [CrossRef]

Sheskin, David J. 2011. Handbook of Parametric and Nonparametric Statistical Procedures, 5th ed. Boca Raton: Chapman\&Hall/CRC.

Smith, Hyrum L., and Tim Griesdorn. 2014. Do Saving Rules Influence Self-Employed Households' Participation in Tax-Deferred Retirement Plans? American Association of Family and Consumer Sciences Research Journal 43: 47-60. [CrossRef]

Turner, Kea, and Kim Manturuk. 2012. Individual, Institutional, and Structural Determinants of Household Savings Decisions. Working Paper. Chapel Hill: The University of North Carolina at Chapel Hill.

Yang, Ting-Ying, and Sharon A. DeVaney. 2012. Determinants of Retirement Assets and the Amount in Stock in Retirement Assets. Family and Consumer Sciences Research Journal 41: 36-55. [CrossRef]

Zimon, Grzegorz, and Tarighi Hossein. 2021. Effects of the COVID-19 Global Crisis on the Working Capital Management Policy: Evidence from Poland. Journal of Risk and Financial Management 14: 169. [CrossRef] 